\title{
Determining moral leadership as argued from an evolutionary point of view - With reference to gender, race, poverty and sexual orientation
}

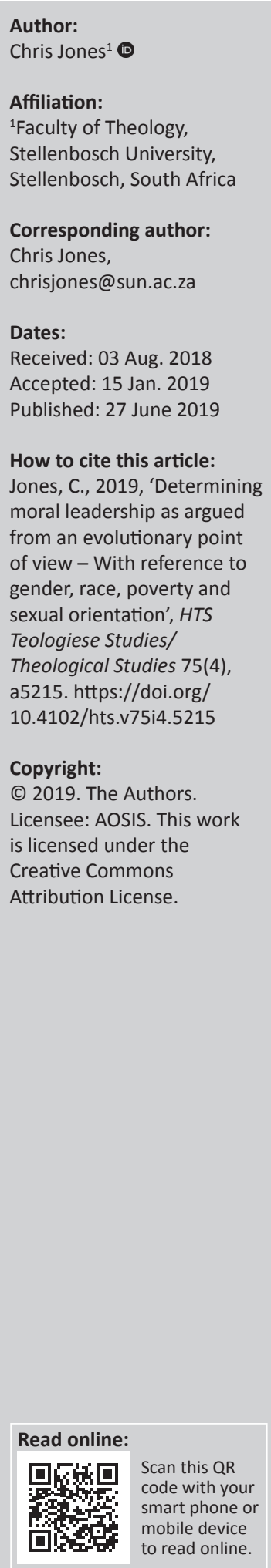

This essay focuses on determining moral leadership, as theoretically debated from an evolutionary point of view in an attempt to reflect on how this kind of moral leadership can contribute, among others, in dealing with issues such as gender, race, poverty and sexual orientation. Although important, not one of the latter issues will be discussed. It is not the primary focus of the essay. But because we are aware of the extent of the challenges regarding these issues, they were specifically identified as examples for applying the moral guidelines developed and determined in this essay. This essay mainly argues that morality and moral leadership require analytical and critical evolutionary thinking and reflection that could contribute to making the world a more just and fair place in which to live. Moral leaders are created when people are constantly striving in an ongoing process of reasoning to become more humane, thereby allowing every person to flourish and to reach their full potential through biologically determined and justice-based moral reflection and action.

Keywords: Moral leadership; Evolutionary science; Biology; Moral codes; Moral sense; Ethical choices; Behaviour; Gender; Race.

\section{Introduction}

Many people around the world are actively engaged in a struggle for a better society - politically, economically, ethnically, sexually and morally, to name but a few aspects. These so-called moral leaders may even risk their lives to achieve this goal. At times, these individuals may, however, become impatient towards the theoretical reasoning that surrounds these issues. There are certain presuppositions and assumptions that often inform people's decision-making and impact the effectiveness of moral leaders' actions. There is thus a constant need for critical examination and assessment of the implicit theory that informs people's actions. By exposing themselves to the ethical and moral assumptions and theories of others, people are compelled to evaluate their own ethical and moral views critically. Engaging in academic debate allows one the opportunity to challenge the presuppositions and moral-ethical assumptions of others.

The presuppositions of society are (partly) sustained by an academic foundation that needs to be constantly reviewed, debated and modified (Villa-Vicencio \& De Gruchy 1994:ix-xi).

José Miguez Bonino (1983), pioneer of Latin American liberation theology, understands and shares the above-mentioned impatience. However, he is also convinced that we:

$[U]$ nderestimate the theoretical task and turn our backs on the theory, only at considerable cost to ourselves and to the effectiveness of our actions. The cost in human life that we pay for simple pragmatism is too high. (p. 9)

Philip Selznick, former Professor of Sociology and Law at the University of California, Berkeley, argues that when people engage in theoretical reasoning, they become part of what he calls the 'moral commonwealth' which forms the basis of ethical and moral behaviour in any age (Selznick 1994:n.p.).

This essay focuses on determining moral leadership, as theoretically debated from an evolutionary point of view in an attempt to reflect on how this kind of moral leadership can (possibly) contribute in dealing with issues such as gender, race, poverty and sexual orientation. 
Morality requires analytical thinking and critical reflection that can (help) make the world a more just and fair place to live. This essay therefore shows that moral leaders are created when people are constantly striving in an ongoing process of reasoning to become more humane, thereby allowing every person to flourish and to reach their full potential through biologically determined and justice-based moral reflection and action.

According to Charles Villa-Vicencio and John de Gruchy, reflection on ethics (and morality) is never only for the sake of reflection. Action is necessary, but it must, in turn, give rise to further reflection and self-critique.

Practising ethics and morality 'involves participation in an action-reflection-action continuum' (Villa-Vicencio \& De Gruchy 1994:xi).

\section{Evolutionary science as a lens}

Firstly, it is important to take cognisance of evolutionary science as defined by David Stamos, a philosopher of Science from York University, Toronto. This view (in line with certain important cultural codes as will be identified later in the essay) could serve as an important lens or window through which broader social realities such as gender, race, poverty and sexual orientation can be viewed and understood. Evolutionary science may furthermore help us to become more aware of injustices and harm done to people when, in the context in which they have been forced to live by society and even their church, they find that they cannot exist as authentic people. Evolutionary science in particular wants to show us who we are as human beings and how we should treat one another in light of this realisation.

This essay makes some suggestions as to how evolutionary science may shed some light on the important question of morality and moral leadership. To orientate ourselves, Darwinian evolution will serve as a point of departure. Even though one rightly could raise some points of critique especially in terms of gender (as will be done later in this article), one cannot deny the importance of evolutionary science. Daniel Dennet has argued that Darwinian evolution is a 'universal acid', corroding its way virtually through all areas of life (Stamos 2008:3).

In this regard, it is important to note that certain scholars (see Badcock 2000; Barkow 1992; Crawford \& Krebs 1998; Pinker 2002; Wilson 1975) argue that the debate is not about nature versus nurture but rather nature-nurture versus nurture. It is not only a debate between two clear-cut models, namely an emphasis on evolutionary history on the one hand and cultural history on the other. Stamos argues that a full explanation for a given trait requires a genetic and ultimately evolutionary explanation (nature) and an environmental explanation (nurture) - in other words a nature-nurture approach (Stamos 2008:4).
We must be wary of efforts to play down the role of biology and play up the role of environment, namely culture and conditioning. Ultimately, this will lead to a view of human nature as plastic or mouldable, according to Stamos (2008:4). One should note that there are many so-called behaviourists who do not really recognise the role of genes in the behaviour of people.

What goes hand-in-hand with behaviourism, both ideologically and temporally, is cultural relativism. The anthropologist, Ruth Bennedict (1934:59), argues that 'mannerisms like the ways of showing anger, or joy, or grief ... or in major human drives like those of sex ... in fields such as that of religion or formal marriage arrangements' are tremendously variable and entirely culturally relative. Therefore, what is considered normal in one society may easily be considered abnormal in another. Thus, no culture, according to such a view, is 'right' and no culture is 'wrong' (Bennedict 1934:73).

It is important to note that the reluctance to talk about genes and human nature invariably involves the fear of biological determinism. The fact that genes influence human behaviour does not mean that they necessarily determine all human behaviour. However, evolutionary biology has to be taken seriously, because it can help us truly to understand the human condition and, in relation to this essay, to gain insight into the phenomenon of the nature and significance of moral choices, actions and leadership.

Although evolutionary explanations of human nature and human behaviour have been around since Darwin, they were neglected in academic disciplines outside of professional biology. Noam Chomsky (Stamos 2008:5), well-known American linguist, philosopher and cognitive scientist, opened the door (since the beginning of the 1950s) to the evolutionary models of human behaviour, namely through socio-biology and evolutionary psychology. Socio-biology, as explained by Stamos (2008), is:

[T] he application of evolutionary principles to help explain social behaviour in humans and other animals, while evolutionary psychology is the application of evolutionary principles to help explain psychological phenomena. These two bargaining fields have much in common and a lot of overlap. (p. 5)

Given that this essay is in line with the objective to partly reflect on gender, among others, one should be cognisant of the criticism that the science of evolutionary biology in itself is sexually biased and has a substantial history of male chauvinism. Therefore, many feminists reject much of the science of evolutionary biology because of what they sometimes call malestream epistemology (Stamos 2008:126), manufactured by men for men. Stamos (2008:126-127), however, says that although he is uncomfortable with what Darwin says about the differences between men and women, he seriously doubts that Darwin would have resisted modern evidence that goes against his conclusions regarding sex 
selection with respect to these differences between man and woman. According to Stamos (2008:127), Darwin was after all 'the pioneer in evolutionary psychology... He was the first word, not the last, and he well knew it'.

Stamos also admits that things have changed in many ways with the advent of civilisation (Stamos 2008:131). He says that although we carry our evolutionary past in our genes or as Darwin (1871:405) has put it, 'the indelible stamp of our lowly origin', civilisation has increasingly changed the rules. Thus:

What was, no longer necessarily ought to be ... [W]ith civilization came the concept of justice, and a robust concept of justice demands that women be treated with respect, as equal beings alongside men. (p. 131)

Stamos (2008:131) further notes that 'justice makes its demands on science too, and there is no reason why science cannot be gradually purged of its harmful elements, of which male chauvinism is but one'. For this to happen, insights from modern feminism are vital and these should be corroborated by findings from the halls and laboratories of science. Although Susan Haack (2003:580-588) suggests a remedy of 'diversity within science', Kathleen Okruhlik (1998:205) calls for 'the inclusion of diverse standpoints'. Many feminist scientists motivated by the ideal of objective knowledge strive to sensitise men and create new terminology. ${ }^{1}$

On the contrary, evolutionary development and science do not discriminate in terms of ethnicity and sexual orientation. All human beings have the same origin. We are a single race. Different human races do not exist. Therefore, according to Stephen Gould (1977:232), we should not name human races. He argues that 'geographic variability, not race, is selfevident' (Gould 1977:232). We have to resist any attempt to reintroduce the concept of race, using ecology or using cladistics taxonomy.

Different sexual orientations are also not social constructs but natural human kinds - patterns emerging during embryological development. Discrimination against any LGBTIQ+ person (lesbian, gay, bisexual, transgender, intersex, queer and the + stands for all other) runs against evolutionary biology and must be rejected.

In the rest of this essay, certain insights from evolutionary science will be brought into conversation with moral leadership and particularly moral leadership in a context that seeks to change minds and hearts with respect to gender,

1.Another interesting perspective in this regard is found in an article by anthropologis Emily Martin in 1991. She is 'intrigued by the possibility that culture shape how biological scientists describe what they discover about the natural world. If this were so, we would be learning about more than the natural world in high schoo biology class; we would be learning about cultural beliefs and practices as if they were part of nature'. In the course of her research she realised 'that the picture of were part of nature. In the course of her research she realised that the picture of egg and sperm drawn in popular as well as scientific accounts of reproductive biology relies on stereo types central to our cultural definitions of male and female. The stereo type imply not only that female biological processes are less worthy than their male counter parts but also that women are less worthy than men'. Part of he goal in writing this article was 'to shine a bright light on the gender stereo type hidden within the scientific language of biology'. Exposed in such a light, she hopes they will lose much of their power to harm us. Read more on this in Martin (1991). race, poverty and sexual orientation. For this purpose, mention will be made of well-established models that reflect on the characteristics of moral leadership. In particular, this essay will reflect on the value of what is called the Four Key Drives theory or model. However, before turning to this model and its significance for cultivating moral leaders, some reflections on the difference between moral sense and moral codes are in order.

\section{Moral sense versus moral codes}

Darwin's distinction between moral sense or conscience on the one hand and moral codes or norms on the other is crucial to the issue at the heart of this essay, that is, the nature and significance of moral leadership in cultivating change. A point of debate between scientists and philosophers is whether moral sense is biologically determined or not. In these debates however, one often finds that people fail to make the distinction between moral sense and moral codes.

Morality is, according to many scientists, a human biological attribute - it is the predisposition to make moral judgements. In other words, without moral sense, which is biologically determined, it would not be possible to judge some actions as good and others as bad or evil. In contrast, some philosophers argue that morality is not biologically determined. Rather, it comes from cultural traditions or religion. In this case, however, they are actually thinking about moral codes - the sets of norms that determine which actions are judged to be good or bad. Francisco Ayala (2012:169) states: 'They point out that moral codes vary from culture to culture and, therefore, are not biologically predetermined'.

There were, however, philosophers throughout the centuries such as, among others, Aristotle, who believed that humans hold moral sense by nature, because a human is not only Homo sapiens, but also Homo moralis (Ayala 2012:169). Ayala compares this distinction between moral sense and moral codes with language where a similar distinction can also be made. He indicates that the capacity for symbolic creative language is determined by our biological nature, but the particular language we speak - for example, English or isiXhosa - is definitely not biologically determined.

Similarly, one could argue that the need for moral values - as biologically determined and influenced - does not (necessarily) tell us what the specific moral values in your life will be - in the same way that the capacity for language does not determine which specific language you will speak. According to Ayala, (2012:170) humans are moral or ethical beings by their biological nature. The ability to evaluate your behaviour as either right or wrong, moral or immoral is a consequence of our intellectual capacities that include selfawareness and abstract thinking. These intellectual capacities are products of the evolutionary process. On the contrary, the moral codes or norms according to which we evaluate particular actions as either morally good or morally bad are products of cultural, not biological, evolution. It is at this 
point that an explanation of the Four Key Drives theory could be helpful.

\section{The Four Key Drives theory}

Perhaps the most noteworthy deduction about human behaviour emerging from Charles Darwin's scientific studies published more than 150 years ago is the notion of the four innate, evolutionary determined and developed key drives. In his The Descent of Man (1871), Darwin affirms that moral sense or conscience is a necessary consequence of high intellectual abilities that we associate with modern human beings. An important point made by Darwin is that having moral sense does not in itself determine what the moral codes or norms in one's life would be. In fact, there is a definite distinction between moral sense and moral codes.

Humans have evolved to survive differently from other animals. We have endured as a species because we have learned to work in groups and rely on problem-solving skills rather than brute force, inborn physical capacities and instincts.

The late Harvard Business School professor Paul Lawrence notes that for a long time, Darwin's insights about human drives were largely ignored. He and Nitin Nohria in Driven: How Human Nature Shapes Our Choices (Lawrence 2010:n.p.) propose a theory of human behaviour based on 'renewed Darwinism' and four key drives that have been further developed by Marc Hauser in his book Moral Minds (2006).

These Four Key Drives are as follows:

- To acquire what we need for survival, conception and our offspring's survival. This drive far surpasses our drives to acquire food, water, warmth and a mate. We are driven to attain things that interest us, give us a sense of identity and meet our loved ones' needs.

- To defend ourselves and our offspring from threats. We protect our family and groups to which we belong, our ideas and beliefs, our sense of pride and hope, and our self-image.

- To bond and form long-term, mutually caring and trusting relationships with others.

- To comprehend - to learn, understand, create, innovate and make sense of the world and our place in it.

A central question in moral leadership would be how to align certain moral codes or norms with these four innate key drives. The reason for this is that all of us find ourselves in a specific human society and cultural context that markedly impacts our behaviour as well as our moral decision-making.

An important point in this regard made by Ayala (2012:174) is that the codes or 'norms of morality must be consistent with biological nature, because ethics can only exist in human individuals and in human societies'. However, before we get to this 'process' of aligning, certain conditions that are necessary for ethical choices and behaviour must first be highlighted.

\section{Three necessary conditions for ethical choices and behaviour}

Given that humans are moral beings by nature, their biological constitution determines the presence (in them) of three necessary conditions for ethical behaviour: (1) the ability to anticipate the consequences of one's own actions; (2) the ability to make value judgements and (3) the ability to choose between alternative courses of action.

These abilities exist, according to Ayala (2012:171-173), as a consequence of the eminent intellectual capacity of human beings. Thus, the ability to anticipate the consequences of one's own actions is the most fundamental of the three conditions required for ethical behaviour. Ayala (2012) explains this condition as follows:

Only if one can anticipate that pulling the trigger will shoot the bullet, which in turn will strike and kill my enemy, can the action of pulling the trigger be evaluated as nefarious. Pulling a trigger is not in itself a moral action, it becomes so by virtue of its relevant consequences. (p. 171)

Therefore, one's action has an ethical dimension the moment one (can) anticipate the consequences. This ability to establish the connection between pulling a trigger and its consequences requires the ability to anticipate the future and to form mental images of realities not present or not yet in existence (Ayala 2012:171).

The second condition regarding the existence of ethical behaviour is the ability to make value judgements; to perceive certain objects or deeds as more desirable than others. Ayala (2012) writes that:

$[O]$ nly if I can see the death of my enemy as preferable to his survival can the action leading to his demise be thought of as moral. If the consequences of actions are neutral with respect to value, an action cannot be characterised as ethical. (p. 172)

However, in all cases, the ability to make value judgements depends on the capacity for abstraction that makes it possible to compare objects or actions with one another and to perceive some as more desirable than others. This seems to exist in humans alone.

The third condition necessary for ethical behaviour is the ability to choose between alternative courses of action. Pulling the trigger can be a moral action only if one has the option not to pull it, reasons Ayala. A necessary action beyond conscious control is not a moral action. It is furthermore a question of what role free will plays. One should note that there would be no ethical behaviour without free will and morality would be an illusion, according to Ayala. Ayala (2012) argues:

[F]ree will is dependent on the existence of a well-developed intelligence, which makes it possible to explore alternative courses of action and to choose one or another in view of the anticipated consequences. (p. 173) 
This is, however, a complex issue. There are new developments in different scientific research fields indicating that our will is not as free as we have thought up till now. ${ }^{2}$

\section{The origin of moral codes}

As already indicated, moral sense is a biological attribute of Homo sapiens, because it is a necessary consequence of our high intelligence. Moral codes, on the contrary, are products of cultural evolution. According to Ayala (2012:174-175), moral codes, like any other cultural system, cannot survive for long if they run in outright contrast to our biology. Humans are bound to their biology. ${ }^{3}$

Furthermore, there is no necessary or logical connection between religious faith and moral codes, although there is usually a motivational or psychological connection. Religious beliefs explain why people accept a particular set of ethical codes or norms because they are motivated to do so by their religious convictions (Ayala 2012:175).

On the contrary, moral codes, those sets of norms that we use to judge behaviour, can differ from culture to culture and also change over time. These norms are influenced by religion and cultural traditions. For many people however, their religious background and belief system are truly the backbone of their ethical thinking. The Dalai Lama reminds us that '... religious belief is no guarantee of moral integrity' (Dalai Lama 2001:27). Further, 'Religion can help us establish basic ethical principles. Yet we can still talk about ethics and morality without having recourse to religion' (Dalai Lama 2001:28).

Moral codes as products of cultural evolution are a distinctive human mode of evolution that, according to Ayala, have surpassed the biological mode because they are faster than the biological mode and because they can be directed. Cultural heredity does not depend on biological inheritance - from parents to children. It is transmitted horizontally and without biological bounds. A cultural mutation, an invention like a laptop, cell phone or rock music, can be extended to millions of individuals in less than one generation (Ayala 2012:176). Therefore, cultural evolution is much faster than biological evolution and it is very attractive and powerful.

Right through the centuries, human societies have experimented with moral systems. Some such as the Ten Commandments have succeeded and spread widely through humankind although other moral systems exist in different human societies. Many moral systems of the past have become extinct because they were replaced or because the societies that held them died out (Ayala 2012:176).

The moral systems that currently exist in humankind are those that were favoured by cultural evolution. They were

2.For more information see Bode 2014, Lavazza 2016, Libet et al. 1983, Soon et al 2008.

3.For further information in this regard, see Merleau-Ponty (2004). propagated within particular societies probably because individuals felt that they were beneficial at least to the extent that they promoted social stability and success. Legal and political systems as well as belief systems are themselves outcomes of cultural evolution (Ayala 2012:176).

Darwin, in the words of Ayala, makes two interesting points in this regard: (1) morality may contribute to the success of some tribes over others, and (2) certain standards of morality will tend to improve over human history because the higher the moral standards of a tribe, the more likely its success. The standards that would contribute to tribal success are patriotism, fidelity, obedience, courage, sympathy and morality. Ayala (2012) therefore argues that:

$[T]$ he codes/norms of morality, as they exist in any particular human society or culture, are felt to be universal within that culture. Nonetheless, like other elements of culture, they are continuously evolving, often within a single generation. (p. 178)

They are not set or fixed.

Thus, the legal and political systems that govern human societies as well as belief systems held by religion are themselves outcomes of cultural evolution as eventuated throughout human history, particularly over the last few millennia (Ayala 2012:178).

\section{Moral codes to be aligned with our biology}

As indicated above, moral codes, like any other cultural system, cannot survive for long if they run contrary to our biology. The question now would be: what kinds of codes (and behaviour) fulfil these four drives in the brains of others without ignoring them in one's own mind and would produce change in oneself and cultivate change in other people? Furthermore, what would these codes (norms) of engagement look like to realise these four innate drives? Thus, these norms should be completely consistent with the innate drives otherwise they would not stand the test of time or survive for too long. In particular, what would be the consequences of this kind of aligning with regard to gender, race, poverty and sexual orientation?

With respect to the first innate drive (acquire), the other's capacity to gain the necessary resources must be enhanced not only one's own. Everyone must be given his or her due in an honest way, and it should be promoted regardless of resentment and anger. This requires restraint and selfsacrifice, simplicity and contentment. A sense of identity must be given to people and their needs must be met as far as possible by actively helping them to prosper and flourish, and by giving them the chance to live a good life.

To 'bond' (the second innate drive), trust, honesty, integrity and the enhancement and building of peace are needed. Forming trustful relationships and interaction with other 
people is of immeasurable value. British contemporary historian Anthony Seldon (2009) asserts that:

$[W]$ e believe that trust is innate, and that we flourish in a trusting world. Performing trustful acts makes us feel happy: there is a natural compulsion to give and receive trust, and to be honest. (p. 25)

To 'comprehend' (third innate drive), knowledge is needed including indigenous knowledge. Josh Kaufmann (2011:n.p.) asserts that we must 'explore new areas of life, practice new skills, and satisfy curiosity'. We must remain teachable, creative and innovative to make sense of the world and our place in it.

According to Stamos, specialisation within any field is extremely important, but if one truly wants to know how the world works, whether the human world or the world of nature, then there is little choice but to welcome interdisciplinary studies with an open mind. If one is genuinely imbued with a spirit of inquiry and a thirst for knowledge, one has to awaken people to other possibilities (Stamos 2008:9-10). Although rationality plays an important role in this regard, information is also conveyed through storytelling, narratives and different (intersectional) encounters with people. Stories - also as experienced and told by children - are powerful and can therefore move people from their comfort zones. Storytelling can change dominant forces. It can be meaningful, purposeful and carry diverse opinions. However, dominant stories can also create boundaries and smother other needed information. The dominant story or stories are not the only stories. There are others that should also be heard for diverse and maximum insights.

To 'defend' (the fourth innate drive), acts of justice and courage are needed. The other, their loved ones and property, identity, ideas, sense of pride, hope and self-image should be protected. These include vulnerable children exposed to the sometimes destructive plans and decisions of adults. Allan Boesak, South African theologian and human rights activist, writes grippingly about the youth of the 'Injustice Must Fall' movement in South Africa and the youth of the Black Lives Matter movement in the United States. Despite the ongoing racism and systemic oppression still felt by their generation after the anti-apartheid struggle and the civil rights struggle, they do not become cynical. They march and fight with courage for justice. 'Those marches ...', Boesak writes, 'are stubbornly, liberatingly inclusive: they are marches for social, racial, gender, and sexual justice. They are recognizing, and joyously affirming, their strength in the righteousness of their rebellion' (Boesak 2017:166).

Lawrence (2010:n.p.) shows that when the above-mentioned four drives, in other words, are expressed as nouns rather than verbs, they yield four core values or norms: prosperity (resources), peace/trust (bond), knowledge (comprehend) and justice (defend).

Good moral leaders hold these Four Key Drives in dynamic balance, says Lawrence (2010:n.p.). Weighing and balancing them all the time, especially when there is conflict. Our brain can be considered a flexible, problem-solving mechanism capable of bringing certain codes in line with our innate, biological drives.

Where one succeeds in doing this one displays good moral leadership. Such leaders may be said to possess wisdom. Unfortunately, people are also capable of (too) much bad, misguided and even evil leadership - think of Hitler and his Nazi doctrines of racial supremacy and inferiority as well as $\mathrm{Mr}$ Robert Mugabe, a Zimbabwean politician and revolutionary who served as Prime Minister of Zimbabwe from 1980 to 1987 and then as President from 1987 to 2017. He will be remembered for statements such as that the only white man you can trust is a dead white man, and that his party should continue to strike fear in the heart of the white man, their real enemy.

I believe in an integrated theory of human behaviour. A theory of leadership that is not only testable, but that will also help us hopefully to do a better job of predicting certain events and outcomes. Where our moral codes are aligned and consistent with our biological nature, realistic sustainable non-discriminatory change can be created. One of my expectations in this regard is that fears and misconceptions among people regarding, among others, gender, race, poverty and sexual orientation will be overcome in this manner; that people will be surprised in strange ways; that this model will help people to imagine across boundaries and cultivate an inner eye regarding the pain, brokenness and marginalisation of others to bring hope and show the world a new way of being human.

\section{Conclusion}

These four innate key drives, determined biologically, in concurrence with the above-mentioned engaging and inclusive codes (and behaviour) to realise, strengthen and fulfil these drives in the lives of people, ought to lie in the heart of moral leadership. This is the only way in which good ethical behaviour will be enhanced and ensured.

According to Warren Bennis, '[o]ur understanding of leadership can be no better than our understanding of what makes humans, all humans, tick - what are the ultimate motivators of our behaviour' (http://proffittmanagement. com/driven-to-lead-4-basic-human-drives). If one enhances someone's capacity to (1) acquire the necessary resources to prosper and flourish; (2) bond effectively, because you embrace, emphasise, include, trust, respect, honour and recognise the other person for who he or she is; (3) comprehend with knowledge not only as conveyed on rational level, but also through storytelling, narratives and different encounters, when well-researched truths, useful experience and tested information and insights are shared; and (4) defend one another because you believe in and act according to justice without favour, fear or prejudice, people's perceptions and behaviour towards women (and men), people who belong to another race, the poor and 
LGBTIQ+ people can be changed. Moral change and revolutions, in the words of Kwame Appiah (2010:xi-xix) from the New York University, still do take place.

I would predict that those who have found ways to satisfy all four drives (at least over time) will feel more fulfilled, be more successful and be better moral leaders than those who have focused on some to the exclusion of others (http:// proffittmanagement.com/4-basic-human-drives-leadersare-driven-but-are-they-balanced).

When working with these issues, it can be very useful, as reasoned above, to distinguish between the concepts of moral conscience and moral norms. It helps us to understand that moral norms change and can also differ between cultures and religions. The evolutionary lens helps us to be on the lookout for universal norms, which relate to all people over all generations and cultures.

Total objectivity is not possible for anyone. It seems important to be reminded that even when we are using the basic drives approach, we are, to a certain extent, locked into our own cultural and religious framework. We tend to interpret and translate the basic drives in terms of our own understanding of the world. This does not mean that when we reflect on the moral norms of our time and situation, our reflections are without any value. Instead, the challenge is to keep on reflecting on these matters - not only for our own benefit, but also for the benefit for all of humankind including for those who come after us.

\section{Acknowledgements Competing interests}

The author declares that he has no financial or personal relationship(s) that may have inappropriately influenced him in writing this article.

\section{References}

Appiah, K.A., 2010, The Honor code. How moral revolutions happen, WW Norton \& Company, New York.

Ayala, F.J., 2012, The big questions. Evolution, Quercus, London.

Badcock, C., 2000, Evolutionary psychology: A critical introduction, Polity Press, Cambridge.
Barkow, J.H. et al., 1992, The adapted mind: Evolutionary psychology and the generation of culture, Oxford University Press, Oxford.

Bennedict, R., 1934, 'Anthropology and the abnormal', Journal of General Psychology 10, 59-82. https://doi.org/10.1080/00221309.1934.9917714

Bode, S. et al., 2014, 'Demystefying "free will": The role of contextual information and evidence accumulation for predictive brain activity', Neuroscience and Biobehavioral Reviews 47, 636-645. https://doi.org/10.1016/j.neubiorev.2014.10.017

Boesak, A.A., 2017, Pharaohs on both sides of the blood-red waters. Prophetic critique on empire: Resistance, justice, and the power of the hopeful Sizwe-A transatlantic conversation, Cascade Books, Eugene, OR

Bonino, J.M., 1983, Toward a Christian political ethics, Fortress Press, Philadelphia, PA.

Crawford, C. \& Krebs, D.L., 1998, Handbook of evolutionary psychology: Ideas, issues, and applications, Erlbaum Associates, Mahwah, NJ.

Dalai Lama, 2001, Ancient wisdom, modern world: Ethics for the new millennium, Little, Brown/Abacus Press, London.

Darwin, C., 1871, The descent of man, and selection in relation to sex, John Murray, London.

Gould, S.J., 1977, 'The race problem', Natural History 83(3) (1974), 8-14, reprinted as 'Why we should not name human races - A biological view', pp. 231-236 in Gould, S., Ever since Darwin: Reflections in natural history, W.W. Norton, New York.

Haack, S., 2003, 'Epistemological reflections of an old feminist', Reason Papers 18(1993), 31-43, reprinted in Theory of knowledge: Classical and contemporary readings, in pp. 580-588 ed L.P. Pojman, Wadsworth, Belmont, CA.

Hauser, M.D., 2006, Moral minds. The nature of right and wrong, Harper-Collins Publishers, New York.

Kaufmann, J., 2011, Driven - Paul R. Lawrence and Nitin Nohria, 12 April, viewed 20 September 2017, from https://joshkaufman.net/driven/

Lavazza, A., 2016, 'Free will and neuroscience: From explaining freedom away to new ways of operationalizing and measuring it', Frontiers in Human Neuroscience 10 262. https://doi.org/10.3389/fnhum.2016.00262

Lawrence, P.R., 2010, Moral leadership as shaped by human evolution, 31 May, viewed 15 March 2017, from https://hbr.org/2010/05/moral-leadership-as-shaped-by

Libet, B., Gleason, C., Wright, E. \& Pearl, D., 1983, 'Time of conscious intention to act in relation to onset of cerebral activity (readiness-potential)', Brain 106, 623-642. https://doi.org/10.1093/brain/106.3.623

Martin, E., 1991, 'The egg and the sperm: How science has constructed a romance based on stereotypical male-female roles', Signs: Journal of Women in Culture and Society 16(3), 485-501. https://doi.org/10.1086/494680

Merleau-Ponty, M., 2004, The world of perception, Routledge, London.

Okruhlik, K., 1998, 'Gender and the biological sciences', Canadian Journal of Philosophy 20(Suppl. 1994), 21-42, reprinted in Philosophy of science, pp. 192-208, ed M. Curd \& J.A. Cover, W.W. Norton, New York.

Pinker, S., 2002, The blank slate: The modern denial of human nature, Viking Penquin, New York.

Science, evolution, and creationism, 2008, Institute of Medicine, National Academy of Sciences, Committee on Revising Science and Creationism: A View from the National Academy of Sciences, National Academies Press, Washington, DC.

Seldon, A., 2009, Trust: How we lost it and how to get it back, Biteback Publishing Ltd, London.

Selznick, P., 1994, The moral commonwealth: Social theory and the promise of community, University of California Press, Berkeley, CA.

Soon, C., Brass, M., Heinze, H. \& Haynes, J., 2008, 'Unconscious determinants of free decisions in the human brain', Nature Neuroscience 11, 543-545. https://doi. org/10.1038/nn.2112

Stamos, D.N., 2008, Evolution and the big questions. Sex, race, religion, and other matters, Blackwell, Oxford.

Villa-Vicencio, C. \& De Gruchy, J., 1994, Doing ethics in context. South African perspectives, theology and praxis, vol. 2, David Philip, Cape Town.

Wilson, E.O., 1975, Sociobiology: The new synthesis, Abridged ed. (1980), Harvard University Press, Cambridge, MA. 